\title{
First report of natural infection of Pepper chat fruit viroid in tomato plants in Thailand
}

K. Reanwarakorn*, S. Klinkong and J. Porsoongnurn

Department of Plant Pathology, Faculty of Agriculture at Kamphaeng Saen, Kasetsart University, Kamphaeng Saen, Nakhon Pathom 73140, Thailand

*E-mail: agrknr@ku.ac.th

Received: 20 Jun 2011. Published: 24 Aug 2011. Keywords: Pospiviroid, Solanaceae

At the end of 2009, 60 leaf samples of tomato plants (Solanum lycopersicum) were collected from the field in Lampang province, Thailand. The plant samples were stunted and had leaf symptoms including necrosis, distortion and discoloration. After initial examination by electron microscopy, that revealed no virus particles, the samples were tested for viroids. Total RNA was extracted using a CTAB method (Tangkanchanapas et al., 2005) and then tested for viroids by reverse transcription-polymerase chain reaction (RT-PCR; Tangkanchanapas et al., 2005). Three different primer sets were employed (Table 1), with the PC2 primer set designed to detect six pospiviroids: Columnea latent viroid (CLVd), Tomato apical stunt viroid (TASVd), Tomato planta macho viroid (TPMVd), Tomato chlorotic dwarf viroid (TCDVd), Potato spindle tuber viroid (PSTVd) and Mexican papita viroid (MPVd). Of the 60 samples collected, three tested positive using the PC2 primer set. The amplified DNA bands from these three positive samples were purified, ligated to pGEM ${ }^{\circledR}-\mathrm{T}$ Easy vector (Promega, Madison, USA) and sent for automated sequencing. Identical $348 \mathrm{bp}$ sequences were obtained from all three isolates and these were deposited in GenBank (Accession Nos. JF446891, JF446892 and JF446893).These sequences shared 99\% identity with a Pepper chat fruit viroid (PCFVd) isolate (FJ409044), previously reported from Netherlands (Verhoeven et al., 2009).

One of the isolates (PCFVd-Thai; JF446893) was further characterised by mechanical transmission onto tomato seedlings (cv. Rutgers).Four weeks after inoculation, the infected plants showed necrosis on leaf veins, petioles and stems, leaf distortion and stunting (Fig. 1), closely matching the symptoms seen on the original tomato plants found in the field. Viroid diseases have previously been reported in Thailand: Citrus exocortis viroid (CEVd) in citrus and tomato, Hop stunt viroid (HSVd) and Grapevine yellow speckle viroid (GYSVd) in grapevine and CLVd in tomato. This is

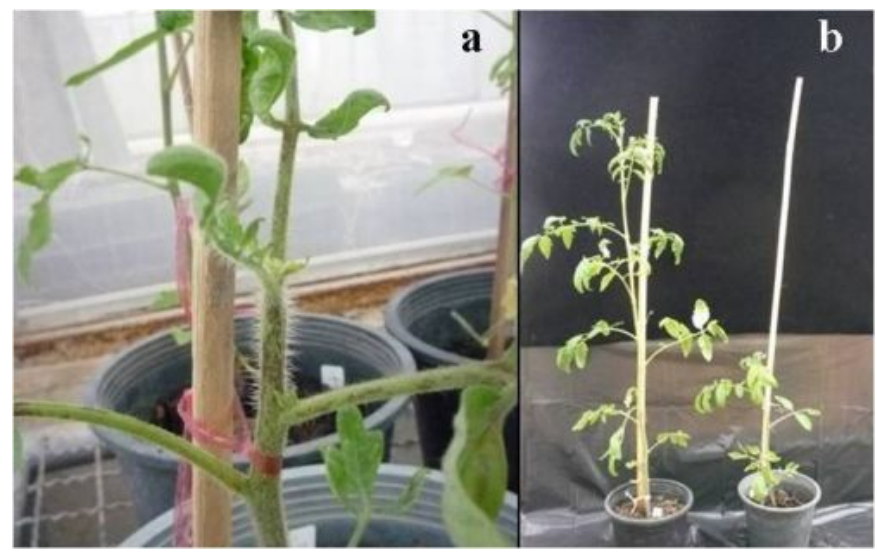

Table 1. Details of primers used to detect tomato viroids.

\begin{tabular}{|c|c|c|c|}
\hline Primer & Sequences & $\begin{array}{l}\text { Target } \\
\text { viroid }\end{array}$ & References \\
\hline CE2 & $\begin{array}{l}\text { cCE2: 5', CCG GGG ATC CCT GAA GGA C 3' } \\
\text { hCE2: 5, GGA AAC CTG GAG GAA GTC GAG } 3 \text {, }\end{array}$ & CEVd & Gross et al,, 1982 \\
\hline HS2 & $\begin{array}{l}\text { cHS2: 5' TCG GAA GAG CCA GAA GG 3' } \\
\text { hHS2: 5, TGA GAC GCGACC GGT GGC ATC ACC T 3, }\end{array}$ & HSVd & Shamloul et al., 2002 \\
\hline PC2 & $\begin{array}{l}\text { cPC2: 5', TGT TTC WRC DGG GAT TAC TCC TG } 3^{\prime} \\
\text { hPC2: } 5 \text { ' GGG TTT TCA CCC TTC CTT TC } 3^{\prime} \\
(\mathrm{W}=\mathrm{A} \text { and } \mathrm{T})(\mathrm{R}=\mathrm{A} \text { and } \mathrm{G})(\mathrm{D}=\mathrm{A} \text { and } \mathrm{G} \text { and } \mathrm{T})\end{array}$ & $\begin{array}{l}\text { CLVd, } \\
\text { MPVd } \\
\text { PSTVd } \\
\text { TASVd } \\
\text { TCDVd } \\
\text { TPMVd }\end{array}$ & $\begin{array}{l}\text { Tangkanchanapas et al., } \\
2005\end{array}$ \\
\hline
\end{tabular}

Figure 2 the first report of PCFVd occurring in the country.

\section{Acknowledgements}

This work was supported by Kasetsart University Research and Development Institute, Kasetsart University, Thailand.

\section{References}

Gross HJ, Krupp G, Domdey H, Raba M, Jank P, Lossow CH, Alberty H, Sanger HL, Ramm K, 1982.Nucleotide sequence and secondary structure of Citrus exocortis and Chrysanthemum stunt viroid.European Journal of Biochemistry 121, 249-257. [doi:10.1111/j.1432-1033.1982.tb05779.x]

Shamloul AM, Faggioli F, Keith JM, Hadidi A, 2002.A novel multiplex RT-PCR probe capture hybridization (RT-PCR-ELISA) for simultaneous detection of six viroids in four genera: Apscaviroid, Hostuviroid, Pelamoviroid, and Pospiviroid.Journal of Virological Methods 105, 115-121. [doi:10.1016/S0166-0934(02)00090-3]

Tangkanchanapas P, Reanwarakorn K, Chanprame S, Hongprayoon R, 2005. An RT-PCR primer pair for the detection of six pospiviroid in tomato plants. Thai Phytopathology 19, 13-21.

Verhoeven JThJ, Jansen CCC, Roenhorst JW, Flores R, de la Peña M, 2009. Pepper chat fruit viroid: biological and molecular properties of a proposed new species of the genus Pospiviroid. Virus Research 144, 209-214. [doi:10.1016/j.virusres.2009.05.002]

Figure 1

To cite this report: Reanwarakorn K, Klinkong S, Porsoongnurn J, 2011. First report of natural infection of Pepper chat fruit viroid in tomato plants in Thailand. New Disease Reports 24, 6. [doi:10.5197/j.2044-0588.2011.024.006] 